\title{
Carcass traits of the naked-neck, dwarf and normal strains of indigenous Tswana chickens under an intensive management system
}

\author{
P. M. Kgwatalala, A. M. Bolowe, K. Thutwa and S. J. Nsoso \\ Department of Animal Science and Production, Botswana College of Agriculture, Private Bag \\ 0027, Gaborone, Botswana
}

\begin{abstract}
The aim of this study was to evaluate carcass characteristics of the naked neck, normal and dwarf strains of indigenous Tswana chickens (ITC). A total of 88 (naked neck: 25 females and 9 males, normal: 14 females and 19 males and dwarf: 11 females and 10 males) ITC were used for the study. The carcass traits evaluated included live weight at 20 weeks of age, carcass weight, dressing percentage, primal cuts (breast, back, drumstick, thigh, wing, neck and shank) weight, giblets (gizzard, liver and heart) weight and feather weight. Sex had a significant influence on carcass characteristics of ITC and males had higher live weight, carcass weight, dressing percentage, primal cuts weight and giblets weight than their age-matched female counterparts. Generally, naked neck males and females had the highest live weight, carcass weight, dressing percentage, primal cuts weight and giblets weight and dwarf males and females had the lowest weights in those parameters. The naked neck strain thus shows the greatest promise for possible selection and development of meat type chicken of ITC.
\end{abstract}

Keywords: Carcass traits, Chicken strains, Intensive management, Tswana chickens

\section{INTRODUCTION}

Indigenous Tswana chickens (ITC) are an important source of animal protein in the form of meat and eggs, contribute to rural food security and are an important avenue for woman empowerment as indigenous Tswana chickens are mostly owned by women. They also improve the rural economy of subsistence farmers through sales of live birds and eggs. Various studies have reported that indigenous chicken meat attract up to thrice the price of broilers meat because of its chewiness, taste, leanness and suitability for special dishes (Crawford, 1992; Igbal et al., 2009 and Jaturasitha et al., 2008). The growth performance of ITC is however very poor relative to that of commercial broilers because of lack of selection for growth potential, poor nutrition, poor housing and poor health care given to the chickens under the traditional free range rearing system.

Moreki (1997) and Badubi et al. (2006) reported the existence of several strains/phenotypes within the indigenous Tswana chickens population such as normal, dwarf, naked-neck, frizzled and rumpless strains. The naked neck, dwarf and frizzled strains occur at a relatively low frequency within the indigenous Tswana chicken population and are at risk of extinction even before they have been characterized in various traits of economic importance. The carcass characteristics (prime cuts inclusive) of various strains of ITC under various rearing systems have not been well documented. The objective of this study was therefore to evaluate carcass characteristics of the naked neck, normal and dwarf strains of indigenous Tswana chickens kept under an intensive management system.

\section{MATERIALS AND METHODS}

Study area: The study was conducted at Botswana College of Agriculture, Content Farm, Sebele, Gaborone in the Southern part of Botswana from September 2011 to February, 2012. During the study period, environmental temperature averaged $33^{\circ} \mathrm{C}$ and ranged between $17.4^{\circ} \mathrm{C}$ and $38^{\circ} \mathrm{C}$.

Experimental animals: A total of 88 ( 25 females and 9 males of naked neck strain, 14 females and 19 males of the normal strain and 11 females and 10 males of the dwarf strain) indigenous Tswana chickens of the same age were used for the study.

Housing and management: Tswana chickens of the naked neck, normal and dwarf strains were housed together in three deep litter houses made from concrete blocks with corrugated iron sheet roofing from day old to 20 weeks of age. Each of the three strains of ITC were thus represented in the three deep litter houses resulting in three replications. The 
chicks were fed chick starter mash ad libitum from day old to 2 weeks of age. At 3 weeks of age, the chicks were individually identified using wing bands and thereafter, fed grower pellets until they were 20 weeks of age. Water was provided ad libitum during the brooding and growth phases. During the growth phase, chickens were also administered Newcastle disease vaccine and TASD Gumboro vaccine. Chickens were raised under natural light ( $12 \mathrm{hrs}$ light and $12 \mathrm{hrs}$ dark periods) throughout the study period.

Carcass traits measurements: A total of 88 (25 females and 9 males of naked neck strain, 14 females and 19 males of the normal strain and 11 females and 10 males of the dwarf strain) indigenous Tswana chickens were humanely sacrificed at 20 weeks of age. After bleeding for about 3 minutes, the birds were de-feathered, eviscerated and dissected into various primal cuts. The carcass traits measured included pre-slaughter live weights, carcass weight, primal cuts (breast, back, drumstick, thigh, wing, neck and shank) weights, giblets (gizzard, liver and heart) weights and feather weight. The dressing percentage was calculated as a ratio of carcass weight to preslaughter live multiplied by 100 . An electronic balance was used to weigh chickens, the carcasses, the giblets and the various primal cuts.

Statistical Analysis: Data were analysed by SAS version 9.2.1 (2009) using General Linear Model procedures and the model included the fixed effects of strain (normal, naked neck and dwarf), sex (male and female) and the interaction between strain and sex. Results on the carcass traits of three strains of ITC are presented as least square means \pm standard error. Means separation were by paired t-tests with Scheffe's adjustment to correct for unequal number of chickens or sampling units between the strains. Differences between means were declared significantly different at $P \leq 0.05$.

\section{RESULTS AND DISCUSSION}

Males were significantly $(P<0.05)$ heavier than females in all the three strains of Tswana chickens at 20 weeks of age (Table 1 ).

Table 1: Least square means for Carcass traits of male and female naked neck, normal and dwarf strains of Tswana chickens at 20 weeks of age.

\begin{tabular}{|c|c|c|c|c|c|c|}
\hline \multirow{2}{*}{ Carcass Trait } & \multicolumn{2}{|c|}{ Naked Neck } & \multicolumn{2}{|c|}{ Normal } & \multicolumn{2}{|c|}{ Dwarf } \\
\hline & Male & Female & Male & Female & Male & Female \\
\hline Live weight (g) & $\begin{array}{l}2543.68^{\mathrm{a}} \\
\pm 88.55\end{array}$ & $\begin{array}{l}1705.02^{b} \\
\pm 53.13\end{array}$ & $\begin{array}{l}2332.07^{\mathrm{a}} \\
\pm 60.94\end{array}$ & $\begin{array}{l}1567.50^{b} \\
\pm 80.00\end{array}$ & $\begin{array}{l}1859.46^{\mathrm{a}} \\
\pm 84.00\end{array}$ & $\begin{array}{l}1408.62^{b} \\
\pm 80.09\end{array}$ \\
\hline Carcass weight (g) & $\begin{array}{l}1695.69^{\mathrm{a}} \\
\pm 61.09\end{array}$ & $\begin{array}{l}1104.05^{b} \\
\pm 36.65\end{array}$ & $\begin{array}{l}1516.98^{\mathrm{a}} \\
\pm 42.04\end{array}$ & $\begin{array}{l}1024.70^{b} \\
\pm 48.10\end{array}$ & $\begin{array}{l}1171.96^{\mathrm{a}} \\
\pm 57.95\end{array}$ & $\begin{array}{l}874.76^{b} \\
\pm 55.26\end{array}$ \\
\hline Dressing \% & $\begin{array}{l}66.92^{\mathrm{a}} \\
\pm 1.00\end{array}$ & $\begin{array}{l}64.78^{\mathrm{D}} \\
\pm 0.60\end{array}$ & $\begin{array}{l}65.00^{\mathrm{a}} \\
\pm 0.69\end{array}$ & $\begin{array}{c}64.38^{\mathrm{a}} \\
\pm 0.81\end{array}$ & $\begin{array}{l}62.92^{\mathrm{a}} \\
\pm 0.96\end{array}$ & $\begin{array}{l}62.09^{\mathrm{a}} \\
\pm 0.91\end{array}$ \\
\hline Breast weight (g) & $\begin{array}{l}471.28^{a} \\
\pm 16.93\end{array}$ & $\begin{array}{l}306.52^{b} \\
\pm 10.16\end{array}$ & $\begin{array}{l}435.27^{a} \\
\pm 11.65\end{array}$ & $\begin{array}{l}300.44^{b} \\
\pm 13.58\end{array}$ & $\begin{array}{l}325.28^{\mathrm{a}} \\
\pm 16.06\end{array}$ & $\begin{array}{l}248.15^{\mathrm{b}} \\
\pm 15.32\end{array}$ \\
\hline Back weight (g) & $\begin{array}{l}325.99^{a} \\
\pm 19.08\end{array}$ & $\begin{array}{l}230.66^{\mathrm{D}} \\
\pm 11.45\end{array}$ & $\begin{array}{l}319.78^{a} \\
\pm 13.13\end{array}$ & $\begin{array}{l}218.84^{\mathrm{b}} \\
\pm 15.30\end{array}$ & $\begin{array}{l}271.96^{\mathrm{a}} \\
\pm 18.10\end{array}$ & $\begin{array}{l}212.55^{\mathrm{b}} \\
\pm 17.26\end{array}$ \\
\hline $\begin{array}{l}\text { Drumstick weight } \\
\text { (g) }\end{array}$ & $\begin{array}{l}157.72^{\mathrm{a}} \\
\pm 7.98\end{array}$ & $\begin{array}{l}83.14^{b} \\
\pm 6.65\end{array}$ & $\begin{array}{l}136.85^{\mathrm{a}} \\
\pm 5.49\end{array}$ & $\begin{array}{l}79.87^{b} \\
\pm 8.88\end{array}$ & $\begin{array}{l}85.25^{\mathrm{a}} \\
\pm 7.57\end{array}$ & $\begin{array}{l}57.23^{b} \\
\pm 10.02\end{array}$ \\
\hline Thigh weight (g) & $\begin{array}{l}180.30^{\mathrm{a}} \\
\pm 6.82\end{array}$ & $\begin{array}{l}94.82^{b} \\
\pm 5.48\end{array}$ & $\begin{array}{l}149.41^{\mathrm{a}} \\
\pm 4.70\end{array}$ & $\begin{array}{l}94.67^{D} \\
\pm 6.62\end{array}$ & $\begin{array}{l}110.35^{\mathrm{a}} \\
\pm 6.47\end{array}$ & $\begin{array}{l}73.20^{\mathrm{b}} \\
\pm 7.47\end{array}$ \\
\hline Wing weight (g) & $\begin{array}{l}106.80^{\mathrm{a}} \\
\pm 4.43\end{array}$ & $\begin{array}{l}73.99^{b} \\
\pm 3.79\end{array}$ & $\begin{array}{l}104.17^{\mathrm{a}} \\
\pm 3.05\end{array}$ & $\begin{array}{l}69.65^{b} \\
\pm 5.07\end{array}$ & $\begin{array}{c}78.18^{a} \\
\pm 4.20\end{array}$ & $\begin{array}{l}61.30^{b} \\
\pm 5.72\end{array}$ \\
\hline Neck weight (g) & $\begin{array}{l}160.43^{\mathrm{a}} \\
\pm 5.56\end{array}$ & $\begin{array}{l}95.28^{b} \\
\pm 3.33\end{array}$ & $\begin{array}{l}139.95^{\mathrm{a}} \\
\pm 3.82\end{array}$ & $\begin{array}{r}75.89^{b} \\
\pm 4.45\end{array}$ & $\begin{array}{l}128.23^{\mathrm{a}} \\
\pm 5.27\end{array}$ & $\begin{array}{l}78.90^{b} \\
\pm 5.02\end{array}$ \\
\hline Shank weight $(\mathrm{g})$ & $\begin{array}{l}48.67^{a} \\
\pm 2.47\end{array}$ & $\begin{array}{c}38.82^{10} \\
\pm 2.29\end{array}$ & $\begin{array}{l}42.13^{\mathrm{a}} \\
\pm 1.70\end{array}$ & $\begin{array}{l}34.41^{D} \\
\pm 2.95\end{array}$ & $\begin{array}{l}31.56^{\mathrm{a}} \\
\pm 2.35\end{array}$ & $\begin{array}{l}26.56^{\mathrm{D}} \\
\pm 3.33\end{array}$ \\
\hline Liver weight (g) & $\begin{array}{l}31.18^{\mathrm{a}} \\
\pm 2.70\end{array}$ & $\begin{array}{l}29.54^{\mathrm{a}} \\
\pm 1.62\end{array}$ & $\begin{array}{l}29.67^{\mathrm{a}} \\
\pm 1.86\end{array}$ & $\begin{array}{l}27.14^{\mathrm{a}} \\
\pm 2.17\end{array}$ & $\begin{array}{l}22.57^{\mathrm{a}} \\
\pm 2.56\end{array}$ & $\begin{array}{l}28.49^{\mathrm{D}} \\
\pm 2.44\end{array}$ \\
\hline Gizzard weight (g) & $\begin{array}{l}52.52^{a} \\
\pm 3.94\end{array}$ & $\begin{array}{l}42.26^{b} \\
\pm 2.36\end{array}$ & $\begin{array}{l}48.83^{\mathrm{a}} \\
\pm 2.71\end{array}$ & $\begin{array}{l}43.11^{\mathrm{a}} \\
\pm 3.16\end{array}$ & $\begin{array}{l}39.52^{\mathrm{a}} \\
\pm 3.74\end{array}$ & $\begin{array}{l}35.25^{\mathrm{a}} \\
\pm 3.56\end{array}$ \\
\hline Heart weight (g) & $\begin{array}{l}14.60^{\mathrm{a}} \\
\pm 0.70\end{array}$ & $\begin{array}{l}7.56^{\mathrm{b}} \\
\pm 0.42\end{array}$ & $\begin{array}{l}12.03^{\mathrm{a}} \\
\pm 0.48\end{array}$ & $\begin{array}{l}7.50^{\mathrm{b}} \\
\pm 0.56\end{array}$ & $\begin{array}{l}10.18^{\mathrm{a}} \\
\pm 0.66\end{array}$ & $\begin{array}{l}6.23^{b} \\
\pm 0.63\end{array}$ \\
\hline
\end{tabular}

Means with different superscripts within strain for a particular trait are significantly different $(p<0.05)$ 
Several researchers (de Marchi et al., 2005; Daikwo et. al., 2011; Igbal and Pampori, 2008; Thutwa et al., 2012; Isidahomen et al., 2012; Khalid et al., 2012; de Almeida and Zuber, 2010) have reported similar findings in different strains/genotypes of indigenous chickens from various countries. There were also significant $(P<0.05)$ differences in carcass weight, primal cuts and giblet (liver and heart) weights between males and females in all the three strains of Tswana chickens. This can be attributed to the positive correlation that these traits have with preslaughter live weight of the birds. The higher preslaughter live weight of males compared to that of females contributed to significantly heavier primal cuts weight of males than females. However, there were no significant differences in dressing percentage and gizzard weight between males and females of normal and dwarf strains of indigenous Tswana chickens. Significantly higher pre-slaughter live weight, carcass weight, primal cuts weight and giblets (liver and heart) weight in males than females of Tswana chickens is consistent with Isidahomen et al. (2012) who reported similar results in Nigerian indigenous chickens. Similar dressing percentage and gizzard weight between males and females of ITC is consistent with Thutwa et al. (2012). Results of the current study revealed that generally, male Tswana chickens had higher pre-slaughter live weights, higher carcass weight, higher dressing percentage, higher primal cuts weights and giblets weights compared to their female counterparts which is consistent with Cahaner et al. (1993). This could be due to the differences in the hormonal profiles between males and females with the male sex hormones favouring rapid weight gains and muscularity and consequently heavier primal cuts weight.

There were no significant $(P>0.05)$ differences in live weight, carcass weight, primal cuts weight with exception of the thigh, neck and giblets (liver, heart and gizzard) weights between male naked neck and normal strains of Tswana chickens (Table 2). The male naked neck and normal strains had however, significantly heavier pre-slaughter live weighs, carcass weights, dressing percentage, primal cuts weight and giblets weight than their age-matched dwarf counterparts. Galal et al. (2007) showed that the dwarfing gene reduced the plasma concentration of triiodthyronine and body weight compared to the normal size birds in Egyptian indigenous chickens. Mohammed et al. (2005) also reported significantly higher live weight $(1547.2 \pm 274.3 \mathrm{~g}$ versus $1198.3 \pm 257.5 \mathrm{~g}$ ) in the Bare-neck than in the Betwil (dwarf) Sudanese chickens. The male naked neck strain had significantly higher dressing percentage, thigh weight and neck weight but significantly lower feather weight than the normal strain at 20 weeks of age. Generally the naked-neck males of ITC had the highest weights for the all carcass parameters (primal cuts and giblets weight) investigated, followed by the normal males and dwarf males had consistently the lowest weights for all the carcass parameters investigated. Consistently higher weights in various carcass parameters in naked neck males of ITC than in normal males is consistent with Isadahomen et al. (2012) who found similar results in Nigerian indigenous chickens. Hossain et al. (2012) also reported higher live weight, total meat yield, breast meat yield, thigh meat yield, drumstick meat yield, heart yield and gizzard yield in male naked neck chicken of Bangladesh relative to their age-matched normal counterparts. Isadahomen et al. (2012) and Khalid et al. (2012) reported high positive phenotypic correlations between live weight and weight of individual portions or primal cuts in chickens. Consistently lower weights of various carcass parameters (primal cuts and giblets) in males of the dwarf strain relative to both naked neck and normal males could be due to their lower pre-slaughter live weight found in the current study and also previously reported by Kgwatalala et al. (2012).

There were no significant $(P>0.05)$ differences in various carcass parameters investigated except for live weight and neck weight between female naked neck and normal strains of ITC (Table 2). However, female naked neck and normal strains of ITC had significantly higher dressing percentage and weights of the breast, drumstick, thigh, shank, heart and the gizzard than their age-matched dwarf counterparts. Female naked neck ITC had significantly higher live weight, carcass weight and wing weight than their dwarf counterparts while there were no significant differences in the three parameters between the normal and dwarf strains. Higher pre-slaughter live weight in naked neck females of ITC relative to the dwarf strain is consistent with Yakubu (2008) who reported live weights of $1.3 \mathrm{~kg}$ and $1.16 \mathrm{~kg}$ in the naked neck and dwarf hens of Nigerian indigenous chickens, respectively. Just like their male counterparts, female naked neck chickens had the highest values for various carcass parameters investigated (primal cuts and giblets weights) and the dwarf strain had the lowest values with the exception of liver weight where the normal strain had the lowest weight. Higher live weight, carcass weight, shank weight, wing weight and gizzard weight in naked neck 
ITC relative to their normal counterparts is consistent with Isadahomen et al. (2012) who found similar results in Nigerian indigenous chicken. Peters et al. (2010) however, reported significantly higher live weight, dressed weight, heart weight and gizzard weight in the normal strain than in the naked neck strain of scavenging Nigerian indigenous chicken.

Table 2: Least square means for carcass traits of male naked neck, normal and dwarf strains of indigenous Tswana chickens at 20 weeks of age.

\begin{tabular}{|l|c|c|c|}
\hline \multicolumn{1}{|c|}{ Carcass Trait } & Naked neck & Normal & Dwarf \\
\hline Live weight $(\mathrm{g})$ & $2543.68^{\mathrm{a}} \pm 88.55$ & $2332.07^{\mathrm{a}} \pm 60.94$ & $1859.46^{\mathrm{b}} \pm 84.00$ \\
\hline Carcass weight (g) & $1695.69^{\mathrm{a}} \pm 61.09$ & $1516.98^{\mathrm{a}} \pm 42.04$ & $1171.96^{\mathrm{b}} \pm 57.95$ \\
\hline Dressing percentage & $66.92^{\mathrm{a}} \pm 1.00$ & $65.00^{\mathrm{b}} \pm 0.69$ & $62.92^{\mathrm{c}} \pm 0.96$ \\
\hline Breast weight (g) & $471.28^{\mathrm{a}} \pm 16.93$ & $435.27^{\mathrm{a}} \pm 11.65$ & $325.28^{\mathrm{b}} \pm 16.06$ \\
\hline Back weight (g) & $325.99^{\mathrm{ab}} \pm 19.08$ & $319.78^{\mathrm{a}} \pm 13.13$ & $271.96^{\mathrm{b}} \pm 18.10$ \\
\hline Drumstick weight (g) & $157.72^{\mathrm{a}} \pm 7.98$ & $136.85^{\mathrm{a}} \pm 5.49$ & $85.25^{\mathrm{b}} \pm 7.57$ \\
\hline Thigh weight (g) & $180.30^{\mathrm{a}} \pm 6.82$ & $149.41^{\mathrm{b}} \pm 4.70$ & $110.35^{\mathrm{c}} \pm 6.47$ \\
\hline Wing weight (g) & $106.80^{\mathrm{a}} \pm 4.43$ & $104.17^{\mathrm{a}} \pm 3.05$ & $128.28^{\mathrm{b}} \pm 5.27$ \\
\hline Neck weight (g) & $160.43^{\mathrm{a}} \pm 5.56$ & $139.95^{\mathrm{b}} \pm 3.82$ & $31.56^{\mathrm{b}} \pm 2.35$ \\
\hline Shank weight (g) & $48.67^{\mathrm{a}} \pm 2.47$ & $42.13^{\mathrm{a}} \pm 1.70$ & $22.57^{\mathrm{b}} \pm 2.56$ \\
\hline Liver weight $(\mathrm{g})$ & $31.18^{\mathrm{a}} \pm 2.70$ & $29.67^{\mathrm{a}} \pm 1.86$ & $39.52^{\mathrm{b}} \pm 3.74$ \\
\hline Gizzard weight (g) & $52.52^{\mathrm{a}} \pm 3.94$ & $48.83^{\mathrm{ab}} \pm 2.71$ & $10.18^{\mathrm{b}} \pm 0.66$ \\
\hline Heart weight $(\mathrm{g})$ & $14.60^{\mathrm{a}} \pm 0.70$ & $12.03^{\mathrm{ab}} \pm 0.48$ & $103.56^{\mathrm{a}} \pm 7.47$ \\
\hline Feather weight $(\mathrm{g})$ & $93.54^{\mathrm{a}} \pm 7.87$ & $153.88^{\mathrm{b}} \pm 5.42$ & \\
\hline
\end{tabular}

Means with different superscripts within a row are significantly different $(p<0.05)$

There were no significant differences in feather weight between the naked neck and the dwarf strain in both sexes but the normal strain had significantly higher feather weight than the two strains in both sexes. Both males and females of the naked neck strain had the lowest values for feather weight and the normal strain had the highest values for feather weight. Superior performance of both males and females of the naked neck strain of ITC in carcass traits (live weight, carcass weight and dressing percentage) and consequently in primal cuts (breast, back, drumstick, thigh, wing, neck and shank) weights is consistent with several studies that reported a favourable effect of the naked neck gene in growth performance of indigenous chickens (Yakubu et al., 2008; Patra et al., 2002; Fathi et al., 2008; Reddy et al., 2008). According to Singh et al. (2001) and Fathi et al. (2008) the naked neck gene reduces feather cover in chickens (see also tables 2 and 3 ) leading to better heat dissipation and a reduction in heat stress. This consequently preserves energy or protein that would have been used for thermal homeostasis and feather growth and avails more energy/protein for productive functions including muscle growth or weight gains (Yakubu et al., 2008; Mahrous and Radwan, 2011). 
Table 3: Least square means for carcass traits of female naked neck, normal and dwarf strains of indigenous Tswana chickens at 20 weeks of age.

\begin{tabular}{|c|c|c|c|}
\hline Carcass Trait & Naked neck & Normal & Dwarf \\
\hline Live weight (g) & $1705.02^{a} \pm 53.13$ & $1567.50^{b} \pm 80.00$ & $1408.62^{b} \pm 80.09$ \\
\hline Carcass weight (g) & $1104.05^{\mathrm{a}} \pm 36.65$ & $1024.70^{\mathrm{ab}} \pm 48.10$ & $874.76^{b} \pm 55.26$ \\
\hline Dressing percentage & $64.78^{\mathrm{a}} \pm 0.60$ & $64.38^{\mathrm{a}} \pm 0.81$ & $62.09^{b} \pm 0.91$ \\
\hline Breast weight (g) & $306.52^{a} \pm 10.16$ & $300.44^{a} \pm 13.58$ & $248.15^{b} \pm 15.32$ \\
\hline Back weight (g) & $230.66^{\mathrm{a}} \pm 11.45$ & $218.84^{a} \pm 15.30$ & $212.55^{\mathrm{ab}} \pm 17.26$ \\
\hline Drumstick weight (g) & $83.14^{a} \pm 6.65$ & $79.87^{a} \pm 8.88$ & $57.23^{b} \pm 10.02$ \\
\hline Thigh weight (g) & $94.82^{a} \pm 5.48$ & $94.67^{a} \pm 6.62$ & $73.20^{b} \pm 7.47$ \\
\hline Wing weight $(g)$ & $73.99^{a} \pm 3.79$ & $69.65^{\mathrm{ab}} \pm 5.07$ & $61.30^{b} \pm 5.72$ \\
\hline Neck weight (g) & $95.28^{a} \pm 3.33$ & $75.89^{b} \pm 4.45$ & $78.90^{\mathrm{ab}} \pm 5.02$ \\
\hline Shank weight $(\mathrm{g})$ & $38.82^{a} \pm 2.29$ & $34.41^{\mathrm{a}} \pm 2.95$ & $26.56^{b} \pm 3.33$ \\
\hline Liver weight (g) & $29.54^{\mathrm{a}} \pm 1.62$ & $27.14^{\mathrm{a}} \pm 2.17$ & $28.49^{\mathrm{a}} \pm 2.44$ \\
\hline Gizzard weight (g) & $42.26^{a} \pm 2.36$ & $43.11^{a} \pm 3.16$ & $35.25^{\mathrm{b}} \pm 3.56$ \\
\hline Heart weight (g) & $7.56^{\mathrm{a}} \pm 0.42$ & $7.50^{\mathrm{a}} \pm 0.56$ & $6.23^{\mathrm{b}} \pm 0.63$ \\
\hline Feather weight & $66.84^{\mathrm{a}} \pm 14.9$ & $135.99^{b} \pm 15.40$ & $89.74^{a} \pm 16.65$ \\
\hline
\end{tabular}

Means with different superscripts within a row are significantly different $(p<0.05)$

\section{CONCLUSION}

The naked neck strain of ITC had the highest live weight, carcass weight, dressing percentage, primal cuts weight and giblets weight and the dwarf strain of ITC had the lowest weights in those parameters. The naked neck strain therefore shows the greatest potential for future selection and development of a meat type ITC.

\section{ACKNOWLEDGEMENT}

The authors would like to thank Botswana College of Agriculture for funding the study.

\section{REFERENCES}

Badubi, SS, Rakereng, M and Marumo, M. (2006). Morphological characteristics and feed resources available for indigenous chickens in Botswana. Livestock Research for Rural Development 18(1).

Crawford, RD. (1992). A global review of the genetic resources of poultry. In: Hodges (1992) ed. The management of global animal genetic resources.
Proceedings of an FAO Expert Consultation. Rome, Italy, April 1992, 205-211.

Daikwo, IS, Okpe, AA, and Ocheja JO. (2011). Phenotypic Characterization of Local Chickens in Dekina. International Journal of Poultry Science. 10: 444-447.

De Almeida, AM, and Zuber, U. (2010). The effect of the Naked Neck genotype (Nana), feeding and outdoor rearing on growth and carcass characteristics of free range broilers in a hot climate. Tropical Animal Health and Production. 42: 99-107

De Marchi, MM, Cassandro, M, Lunardi, E, Baldan, G and Siegel, PB. (2005). Carcass Characteristics and Qualitative Meat Traits of the Padovana Breed of Chicken. International Journal of Poultry Science 4: 233-238

Fathi, MM, El-Attar, AH, Ali, UM and Nazmi, A. (2008). Effect of the neck neck gene on carcass composition and immune competence in chicken. British Poultry Science. 49:103-110. 
Hossain, MM, Nishibori, M and Islam, MA. (2012). Meat yield from broilers, naked neck and full feathered chicken of Bangladesh. The Agriculturists. 10:55-67.

Igbal, S and Pampori, ZA. (2008). Production Potential and qualitative traits of indigenous chicken of Kashmir. Livestock Research for Rural Development 20(11)

Igbal, S, Pampori, ZA and Hasin, D. (2009). Carcass and egg characteristics of indigenous chicken of Kashmir (Kashmir Favorella). Indian Journal of Animal Research. 43: 194-196.

Isidahomen, C E, Ilori BM and Akano, K. (2012). Genetic and Sex Differences in Carcass Traits of Nigerian Indigenous Chickens. Journal of Animal Science Advances. 2: 637-648.

Jaturasitha, S, T. Srinkanchai, T, Kreuzer, M and Wicke, M. (2008). Differences in Carcass and Meat Characteristics between Chicken Indigenous to Northern Thailand (Black-Boned and Thai Native) and Imported Extensive Breeds (Bresse and Rhode Island Red). Poultry Science. 87: 160-169.

Kgwatalala, PM., Nogayagae, M and Nsoso, SJ. (2012). Growth performance of different strains of indigenous Tswana chickens under intensive management system. African Journal of Agricultural Research 7: 2438-2445.

Khalid, AM, Yousif, IA, Omer, MI and Elamin, KM. (2012). Genetic variability of body composition traits in Sudanese Native large Beladi Chicken. Agriculture and Biology Journal of North America. 3: 69-76.

Mahrous, MY and Radwan, LM.(2011). Impact of naked neck (NA) gene, sex, and their interaction on live growth performance and carcass characteristics of broiler chicks under summer season of Egypt. Egyptian Poultry Science. 31: 845-853.

Mohammed, MD, Abdalsalam, YI, Kheir, AM, Jin-yu, W, Hussein, MH. (2005). Comparison of the egg characteristics of different Sudanese Indigenous Chickens. International Journal of Poultry Science. 4:455-457.
Moreki, JC. (1997). Small-scale poultry production systems in Serowe-Palapye Sub-district (Botswana). Master of Applied Science in Agriculture Thesis, University of Melbourne, Melbourne, Australia.

Patra, BN, Bais, RKS, Prasad, RB and Singh, BP. (2002). Performance of naked neck versus normally feathered coloured broilers for Growth, Carcass Traits and Blood Biochemical Parameters in Tropical Climate. AsianAustralian Journal of Animal Science. 15: 1776-1783.

Peters, SO, Idowu, OMO, Agaviezor, BO, Egbede, RO and Fafiolu, AO. (2010). Genotype and Sex Effect on Gastrointestinal Nutrient Content, Microflora and Carcass Traits in Nigerian Native Chickens. International Journal of Poultry Science 9:731-737.

Reddy, BLN, Sharma, RP, Niranjan, M and Chatterjee, RN. (2008). Evaluation of performance of Naked neck $(\mathrm{Na} / \mathrm{Na}, \mathrm{Na} / \mathrm{na})$ and dwarf (dw/dw, dw/-) gene lines under low selection intensity. Indian Journal of Animal Science. 78:975-79.

SAS institute (2009). User's Guide Version, 9.2.1, 20022009, SAS institute Inc., Cary, NC, USA.

Singh, CV, Kummer, D and Singh YP. (2001). Potential usefulness of the plumage reducing Naked Neck (Na) gene in poultry production at normal and high ambient temperatures. World Poultry Science Journal.57:139156.

Thutwa, K, Nsoso, SJ, Kgwatalala, PM and Moreki, JC. (2012). Comparative Live Weight, Growth Performance, Feed Intake, Carcass Traits and Meat Quality in Two Strains of Tswana Chickens Raised Under Intensive System in South East District of Botswana. International Journal of Applied Poultry Research. 1: 21-26.

Yakubu, A, Ogah, DM and Barde, RE. (2008). Productivity and egg quality characteristics of free range naked neck and normal feathered Nigerian indigenous chickens. International Journal of Poultry Science. 7:579-585. 